\title{
Probiotic feeding improves the immunity of pacus, Piaractus mesopotamicus, during Aeromonas hydrophila infection
}

\author{
Thaís Heloísa Vaz Farias a,b ${ }^{\mathrm{a}}$, Nycolas Levy-Pereira ${ }^{\mathrm{a}}$, \\ Lindomar de Oliveira Alves ${ }^{\mathrm{a}}$, Danielle de Carla Dias ${ }^{\mathrm{c}}$, Leonardo Tachibana ${ }^{\mathrm{c}}$, \\ Fabiana Pilarski ${ }^{a}$, Marco Antonio de Andrade Belo ${ }^{\mathrm{b}, \mathrm{d}, *}$, \\ Maria José Tavares Ranzani-Paiva ${ }^{\mathrm{c}}$ \\ a Aquaculture Center of São Paulo State University (CAUNESP), Rodovia Paulo Donato Castellane, s/n, CEP 14884-900 Jaboticabal, SP, \\ Brazil \\ b Department of Preventive Veterinary Medicine, São Paulo State University, Rodovia Paulo Donato Castellane, s/n, CEP 14884-900 \\ Jaboticabal, SP, Brazil \\ c Fishery Institute (APTA-SAA), Av. Francisco Matarazzo, 455, CEP 05001-970, São Paulo, SP, Brazil \\ ${ }^{d}$ College of Veterinary Medicine, Camilo Castelo Branco University, Av. Hilário da Silva Passos, 950, CEP 13690-000 Descalvado, SP, Brazil
}

\section{A R T I C L E I N F O}

\section{Article history:}

Received 22 November 2014

Received in revised form 29 October 2015

Accepted 2 November 2015

\section{Keywords:}

Bacterial infection

Bacillus

Immunostimulation

Innate immune system

Piaractus mesopotamicus

\begin{abstract}
A B S T R A C T
The utilization of probiotic bacteria have been widely tested and applied in intestinal microflora modulation, through competitive exclusion of the pathogenic bacteria. Aeromonas hydrophila is a gram-negative bacterium, responsible for fish outbreaks in farms around the world, and is one of the major loss causes for neotropical fish farmers. 660 pacus $(67 \pm 7 \mathrm{~g})$ were distributed in 20 tanks $(n=33)$, constituting five groups (four tanks for each treatment): four groups were fed with different levels $\left(2,4,8\right.$ and $\left.16 \mathrm{~g} \mathrm{~kg}^{-1}\right)$ of Bacillus cereus and Bacillus subtilis $\left(1: 1,10^{8} \mathrm{CFU} \mathrm{g}^{-1}\right)$, and the fifth group was fed with a control diet (without probiotic). Pacus fed with probiotic showed increment in the ROS production associated to elevated neutrophil and monocyte counts and increased phagocytic activity without affecting the growth parameters. Probiotic fed fish presented higher survival rates, subjected to an i.p. challenge with $10^{8} \mathrm{CFU} \mathrm{mL}^{-1}$ of $A$. hydrophila. The results demonstrated a dose response effect and the ideal level of the probiotic (Bacillus cereus and Bacillus subtilis, $1: 1,10^{8} \mathrm{CFU} \mathrm{g}^{-1}$ ) in $P$. mesopotamicus diets was around $8 \mathrm{~g} \mathrm{~kg}^{-1}$, as the highest survival rates and immunological responses were found in groups of fish fed with this diet. In addition, too much probiotic should be avoided, as pacus fed diet with $16 \mathrm{~g} \mathrm{~kg}^{-1}$ showed partial suppression of these responses.
\end{abstract}

(C) 2015 Elsevier B.V. All rights reserved.

\section{Introduction}

Aeromonas hydrophila is a gram negative, motile, rod-shaped bacterium, widely known as an opportunist pathogen of farmed fish, with worldwide distribution. In rearing systems, in which occurs stressful conditions, this bacterial agent is responsible for disease outbreaks, as described in east Asia (Xia et al., 2004; Crumlish et al., 2010), Europe (Boran et al.,

\footnotetext{
* Corresponding author at: Department of Preventive Veterinary Medicine, São Paulo State University, Rodovia Paulo Donato Castellane, s/n, CEP 14884-900 Jaboticabal, SP, Brazil. Tel.: +55 016999617299.

E-mail address: maabelo@hotmail.com (M.A.d.A. Belo).
} 
2013), middle East (Ahmed and Shoreit, 2001; Sarkar et al., 2012), North America (Pridgeon et al., 2013; Li et al., 2013) and South America (Reque et al., 2010; Silva et al., 2012), being responsible for considerable economic losses in intensive rearing systems.

Also known as hemorrhagic septicemia, the motile $A$. hydrophila infection is characterized by ulcerative lesions on the skin surface, local hemorrhages in gills and opercula, exophthalmia, liquid accumulation in the coelomic cavity, anemia and liver and kidney lesions (Crumlish et al., 2010; Silva et al., 2012). Aeromoniosis is one of the main diseases in farmed pacu (Piaractus mesopotamicus), a neotropical freshwater species of great importance in Brazilian finfish aquaculture, and this teleost fish has demonstrated to be a good bioindicator of water quality and has been used as model for ecotoxicity studies during the process of chemical registrations in Brazil (Castro et al., 2014a). Among the chemicals available for bacterial disease treatment, oxytetracycline and florfenicol are most frequently used in aquaculture (Rigos and Troisi, 2005), and, in some countries, they are the only drugs allowed for fish treatment. The lack of control in antibiotic use, especially for prevention, can trigger undesirable effects in fish, terrestrial animals and environment, which could threaten human health (Cabello, 2006). The use of immunostimulants, as dietary supplements, can improve the innate defense of fish which provide resistance to pathogens, such as vitamins (Belo et al., 2012, 2014), minerals (Castro et al., 2014b, 2014c), essential fatty acids (Sakabe et al., 2013) and yeast Saccharomyces cerevisiae (Reque et al., 2010; Castro et al., 2014b). In this context, many studies regarding probiotic-use in farmed animals have reported improvements not only on the productivity indexes in fish, but also in promoting the welfare and maintenance of host health, especially through gut microbiota modulation, inhibition of pathogen colonization in the intestinal epithelium and stimulation of the innate immune system (Yanbo and Zirong, 2006; Zhou et al., 2009; Ai et al., 2011), when used at the appropriate levels.

In aquaculture, the inclusion of exogenous Bacillus in fish diets have shown a positive overall effect, improving the productive parameters and immune responses and increasing the resistance to pathogens (Raida et al., 2003; Salinas et al., 2005; Merrifield et al., 2010; Nayak, 2010; Sun et al., 2010; He et al., 2011). In this context, the present study aimed to evaluate the effect of diets containing 2, 4, 8 and $16 \mathrm{~g} \mathrm{~kg}^{-1}$ of probiotic (Bacillus cereus and Bacillus subtilis, $1: 1,10^{8} \mathrm{CFU} \mathrm{g}^{-1}$ ) on productivity performance, innate immune parameters and resistance to experimental infection by $A$. hydrophila in pacus, P. mesopotamicus.

\section{Materials and methods}

\subsection{Fish and feeding}

P. mesopotamicus juveniles, from a commercial fish farm (Águas Claras, Mococa-SP), were maintained for 15 days in $500 \mathrm{~L}$ plastic tanks and fed with basal diet (commercial diet) in order to allow them to acclimate to experimental conditions. 660 fish $(67 \pm 7 \mathrm{~g})$ were distributed in 20 tanks $(n=33$; four tanks for each treatment) with continuous water flow $\left(\sim 16 \mathrm{~L} \mathrm{~min}^{-1}\right)$ and artificial aeration. No differences were observed among the water quality parameters throughout the trial period (temperature: $26.6^{\circ} \mathrm{C}, \mathrm{pH}: 7.9 \pm 0.09$, dissolved oxygen: $6.7 \pm 0.59 \mathrm{mg} \mathrm{L}^{-1}$ and ammonia: $0.12 \pm 0.11 \mathrm{mg} \mathrm{L}-1$ ).

Five experimental diets were prepared: one without probiotic (control diet) and four with different levels (2, 4, 8 and $16 \mathrm{~g} \mathrm{~kg}^{-1}$ ) of the commercial probiotic PAS-TR ${ }^{\mathrm{TM}}$ (Bacillus cereus and Bacillus subtilis in a 1:1 proportion, lyophilized at a concentration of $\left.10^{8} \mathrm{CFU} \mathrm{g}^{-1}\right)$. Count of colony forming units of Bacillus cereus and Bacillus subtilis incorporated in Piaractus mesopotamicus diets was performed before the start of the experiment and the reisolation results showed $1.6 \times 10^{1}$,

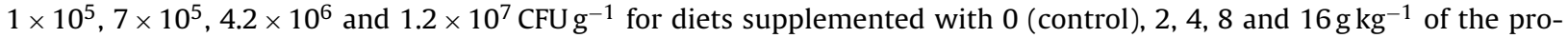
biotic, respectively. Every week during the feeding period, the probiotic was incorporated in the pellets via soybean oil ( $20 \mathrm{~g} \mathrm{~kg}^{-1}$ of diet), mixed manually and the diets were stored at $4{ }^{\circ} \mathrm{C}$ (refrigerated). The control diet was made with the same commercial feed (32\% crude protein, $7 \%$ crude fiber and $6.5 \%$ fat, Pirá $32^{\circledR}$ - Guabi Company), also mixed with soybean oil, but without probiotic. The fish were fed a quantity equal to 3\% of their body mass, twice a day, at 9:00 and 17:00, for 60 days.

The protocol for the animal experiment was approved by Ethics Committee on the Use of Animals of São Paulo State University under the protocol $n^{\circ} 22.518 / 10$.

\subsection{Blood samples and NBT assay}

During the feeding period (at days 7, 15, 30 and 60), ten fish per treatment were anesthetized in a benzocaine solution (100 $\mathrm{mg} \mathrm{L}^{-1}$ ) for blood collection from the caudal vein, afterwards the fish were euthanized by deepening anesthesia. White blood cell (WBC) counts were made using a hemocytometer with Natt and Herrick solution. Blood smears for differential leukocyte counts were stained with a combination of May-Grünwald Giemsa and Wright's Method (Belo et al., 2013). For nitro blue tetrazolium (NBT) assay, $0.5 \mathrm{~mL}$ of blood was transferred to $2 \mathrm{~mL}$ plastic tubes containing $15 \mu \mathrm{L}$ of heparin $\left(5.000 \mathrm{IU} \mathrm{mL}^{-1}\right)$. The respiratory burst of leukocytes was measured according to Biller-Takahashi et al. (2013). Briefly, $100 \mu \mathrm{L}$ of heparinized blood was mixed with $100 \mu \mathrm{L}$ of an NBT-buffered solution (Sigma, St. Louis, MO, USA). The solution was homogenized and incubated in a dark room for $30 \mathrm{~min}$ at $25^{\circ} \mathrm{C}$. After the incubation, $50 \mu \mathrm{L}$ of the solution was added in $5 \mathrm{~mL}$ tubes containing $1 \mathrm{~mL}$,n-dimethyl-formamide, (DMF, Sigma, St. Louis, MO, USA) and centrifuged at $3000 \mathrm{~g}$ for $5 \mathrm{~min}$. The optical density of the supernatant was measured using a spectrophotometer with a wave length of $540 \mathrm{~nm}$. 


\subsection{Phagocytic parameters}

At the end of the feeding period, 6 fish per treatment (captured randomly in 4 tanks) were used to determine phagocytic activity. One milliliter of a solution containing baker's yeast (Sacharomyces cerevisiae) at concentration of 8.000 cells $\mathrm{mm}^{-3}$ was inoculated in the coelomic cavity of juvenile pacu. After $2 \mathrm{~h}$ (time period determined in previous assay), the fish were anesthetized in benzocaine solution $\left(1 \mathrm{~g} \mathrm{~L}^{-1}\right)$ and euthanized by spinal transection (cervical portion). Through a ventral incision, the inoculation region was washed with $1 \mathrm{~mL}$ of saline solution (1\%). The resulting solution containing phagocytic cells was aspirated with a Pasteur pipet $(3 \mathrm{~mL})$ and centrifuged at $250 \mathrm{~g}$ for $5 \mathrm{~min}$ in $5 \mathrm{~mL}$ plastic tubes. The supernatant was dispensed, and the resting cells (in the bottom of the tube) were placed between a glass slide and coverslip to observe the phagocyte count using a contrast phase microscope $(400 \mathrm{X})$. The Phagocytic Index (PI = number of phagocytized particles/number of phagocytizing leukocytes) and Phagocytic Rate ( $\mathrm{PR}=$ number of phagocytizing leukocytes/100 leukocytes) were calculated, according to Silva et al. (2005).

\subsection{Bacterial challenge}

The Aeromonas hydrophila strain used in this assay was acquired from the Laboratory of Aquatic Organisms Pathology (LAPOA) strain collection, of the Aquaculture Center of UNESP (CAUNESP, Jaboticabal, SP, Brazil). The strain was isolated from a hemorrhagic septicemia-diagnosed fish into differential medium for the selective isolation of motile aeromonads (R-S agar) according to Shotts and Rimler (1973). Using an $\mathrm{LC}_{50}$ assay, the concentration required to kill $50 \%$ of fish was $1.0 \times 10^{8} \mathrm{CFU} \mathrm{mL}^{-1}$. The bacteria were stored at $-70^{\circ} \mathrm{C}$ until the day of inoculation. An aliquot of $A$. hydrophila was thawed and inoculated in TSB broth at $25^{\circ} \mathrm{C}$ for $48 \mathrm{~h}$. The bacteria were subsequently centrifuged and washed three times in PBS solution, and the concentration was adjusted to $1.0 \times 10^{-8} \mathrm{CFU}$.

After 60 days of probiotic feeding, 20 fish of each treatment (five per tank) were anesthetized in aqueous solution of benzocaine $(1: 10,000)$, and $1 \mathrm{~mL}$ of the solution containing the bacteria was inoculated in each fish's coelomic cavity. Mortality and clinical signs were observed every $12 \mathrm{~h}$ during the 15 days after the challenge. The diagnosis of $A$. hydrophila infection was made by the isolation of these bacteria in pure culture of the head kidney and by clinical signs observations. Survival rate was calculated in accordance with the following equation:

$$
\text { Survival(Sur) }=\left[1-\frac{\text { number of dead fish }}{20}\right] \times 100
$$

\subsection{Statistical analysis}

The phagocytosis data was analyzed using MIXED procedure (SAS, 2008) and the analysis of variance for comparing the different experimental groups were estimated on the basis of Tukey-Kramer test $(p<0.05)$, and were tested the linear and quadratic effects by orthogonal polynomial contrasts. Survival data was analyzed by LIFETEST procedure (SAS, 2008). For this analysis the data was transformed into LOGIT in COFTYPE option, and the comparison between treatments was performed using the Wilcoxon test and the interaction treatments vs. time was used to HAZARDRATIO option in PHREG procedure. Correlations between respiratory burst activity values and absolute number of neutrophil plus monocyte counts in the blood were made using Spearman Test (GraphPad Prism ${ }^{\circledR}$ software, version 5.0), since the assumption of data normality was previously tested, but both parameters did not pass in the Kolmogorov-Smirnov normality test.

\section{Results}

\subsection{Productivity parameters}

After 60 days of the feeding trial, probiotic inclusion in juvenile P. mesopotamicus diets had no effect on overall weight gain, daily weight gain, feed conversion ratio, specific growth rate and consumption when compared with the control group. No mortality was observed during the experimental period (before the bacterial challenge) (Table 1).

\subsection{NBT assay and leukocyte counts}

Positive correlation $(p=0.0002)$ was observed between respiratory burst activity values and absolute number of neutrophil plus monocyte counts in the 168 blood samples (Table 2), demonstrating the increase of ROS production associated to high number of these leucocytes. Fish fed diet without probiotic $\left(0 \mathrm{~g} \mathrm{~kg}^{-1}\right)$ or supplemented with $16 \mathrm{~g} \mathrm{~kg}^{-1} \mathrm{did}_{\text {not show }}$ statistical significance for this correlation (Table 2), while pacu fed with 2 and $8 \mathrm{~g} \mathrm{~kg}^{-1}$ of probiotic showed 70.08 and $31.15 \%$ of positive correlation between both parameters. Although fish fed $4 \mathrm{~g} \mathrm{~kg}^{-1}$ has positive correlation of $25.77 \%$, these findings were not statistically significant (Table 2). 
Table 1

Production parameters of Piaractus mesopotamicus after 60 days on diets containing different levels of probiotic (Bacillus cereus and Bacillus subtilis, 1:1, $\left.10^{8} \mathrm{CFU} \mathrm{g}^{-1}\right)$.

\begin{tabular}{|c|c|c|c|c|c|c|c|c|}
\hline \multirow[t]{2}{*}{ Productivity parameters ${ }^{\mathrm{a}}$} & \multicolumn{5}{|c|}{ Probiotic $\left(\mathrm{g} \mathrm{kg}^{-1}\right)$} & \multirow[t]{2}{*}{$\mathrm{SE}^{\mathrm{b}}$} & \multirow[t]{2}{*}{$\mathrm{CV}^{\mathrm{b}}$} & \multirow[t]{2}{*}{$p^{\mathrm{b}}$} \\
\hline & 0 & 2 & 4 & 8 & 16 & & & \\
\hline$W_{\mathrm{i}}(\mathrm{g})$ & 64.81 & 64.01 & 72.48 & 66.51 & 68.16 & 3.97 & 11.83 & 0.5942 \\
\hline$W_{\mathrm{f}}(\mathrm{g})$ & 140.10 & 136.10 & 131.09 & 134.15 & 133.06 & 6.30 & 9.35 & 0.8772 \\
\hline WG $(\mathrm{g})$ & 75.28 & 72.06 & 58.61 & 67.64 & 64.90 & 4.59 & 13.58 & 0.1494 \\
\hline DWG $\left(\right.$ g day $\left.^{-1}\right)$ & 1.25 & 1.19 & 0.98 & 1.13 & 1.07 & 0.07 & 13.57 & 0.1494 \\
\hline DC $\left(\right.$ g day $\left.^{-1}\right)$ & 2.50 & 2.52 & 2.57 & 2.38 & 2.57 & 0.05 & 3.95 & 0.1222 \\
\hline FCR & 2.00 & 2.09 & 2.78 & 2.13 & 2.40 & 0.21 & 18.23 & 0.1021 \\
\hline SGR $\left(\right.$ g day $^{-1}$ ) & 1.28 & 1.25 & 0.97 & 1.17 & 1.12 & 0.07 & 12.44 & 0.0591 \\
\hline
\end{tabular}

a $W_{\mathrm{i}}$ is the weight (initial); $W_{\mathrm{f}}$ is the weight (final); WG is the weight gain $\left(\mathrm{WG}=W_{\mathrm{f}}-W_{\mathrm{i}}\right)$; DWG is the daily weight gain (DWG $=W G / t ;$ where $t=$ time in days); $\mathrm{DC}$ is the daily consumption; FCR is the feed conversion ratio (FCR $=$ feed intake/weight gain); $\mathrm{SGR}$ is the specific growth rate $\left\{\mathrm{SGR}=\left[\left(\ln W_{\mathrm{f}}-\ln W_{\mathrm{i}}\right) / t\right]\right.$ * 100 , where $t=$ time in days, $\ln =$ natural logarithm\}.

b $\mathrm{SE}$ is the standard error; $\mathrm{CV}$ is the coefficient of variation; $p$ is the probability of significance.

Table 2

Correlation analysis between respiratory burst activity values and absolute number of neutrophil plus monocyte counts in the blood of pacus fed diets with different levels of probiotic.

\begin{tabular}{|c|c|c|c|}
\hline \multirow[t]{2}{*}{ Correlated parameters $^{a}$} & \multirow[t]{2}{*}{ Experimental sampling ${ }^{\mathrm{b}}$} & \multicolumn{2}{|c|}{ Correlation analysis } \\
\hline & & $\rho^{\mathrm{c}}$ & Prob $>|\rho|^{\mathrm{c}}$ \\
\hline \multirow{7}{*}{ Leukocytes $\times$ Burst } & All animals & 0.2848 & 0.0002 \\
\hline & All treated animals & 0.3434 & $<0.0001$ \\
\hline & $0 \mathrm{~g} \mathrm{~kg}^{-1}$ & 0.01905 & 0.9135 \\
\hline & $2 \mathrm{~g} \mathrm{~kg}^{-1}$ & 0.7008 & $<0.0001$ \\
\hline & $4 \mathrm{~g} \mathrm{~kg}^{-1}$ & 0.2571 & 0.0771 \\
\hline & $8 \mathrm{~g} \mathrm{~kg}^{-1}$ & 0.3115 & 0.0474 \\
\hline & $16 \mathrm{~g} \mathrm{~kg}^{-1}$ & -0.01009 & 0.9570 \\
\hline
\end{tabular}

${ }^{a}$ Leukocytes = absolute number of monocyte plus neutrophil counts in the blood; Respiratory burst activity (NBT assays).

b Correlation between all animals $(n=168)$; only animals fed with probiotics $(n=133)$; pacus fed $0 \mathrm{~g} \mathrm{~kg}^{-1}$ $(n=35) ; 2 \mathrm{~g} \mathrm{~kg}^{-1}(n=32) ; 4 \mathrm{~g} \mathrm{~kg}^{-1}(n=29) ; 8 \mathrm{~g} \mathrm{~kg}^{-1}(n=41) ; 16 \mathrm{~g} \mathrm{~kg}^{-1}(n=31)$.

c $\rho$ is the coefficient of Spearman correlation; Prob. $>|\rho|$ is the significance probability of $\rho$ value.

\subsection{Phagocytic activity}

Phagocytic index increase was observed in treated fish (Fig. 1), where the highest value was expressed by the fish that were fed with $8 \mathrm{~g} \mathrm{~kg}^{-1}$. A dose-response effect was observed in pacus fed up to $8 \mathrm{~g} \mathrm{~kg}^{-1}$ of probiotic (Fig. 1). Fish fed diet without probiotic $\left(0 \mathrm{~g} \mathrm{~kg}^{-1}\right)$ presented significant $(p=0.0036)$ decrease in the phagocytic index only when compared to pacu fed with $8 \mathrm{~g} \mathrm{~kg}^{-1}$ (Fig. 1). Increase in the phagocytic rate (Fig. 2) was observed in fish fed with 4,8 or $16 \mathrm{~g} \mathrm{~kg}^{-1} \mathrm{of} \mathrm{the}$

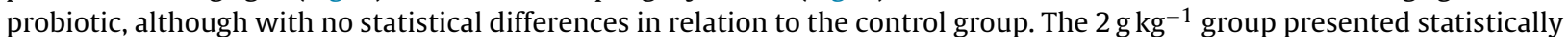
lower values when compared to other treated fish.

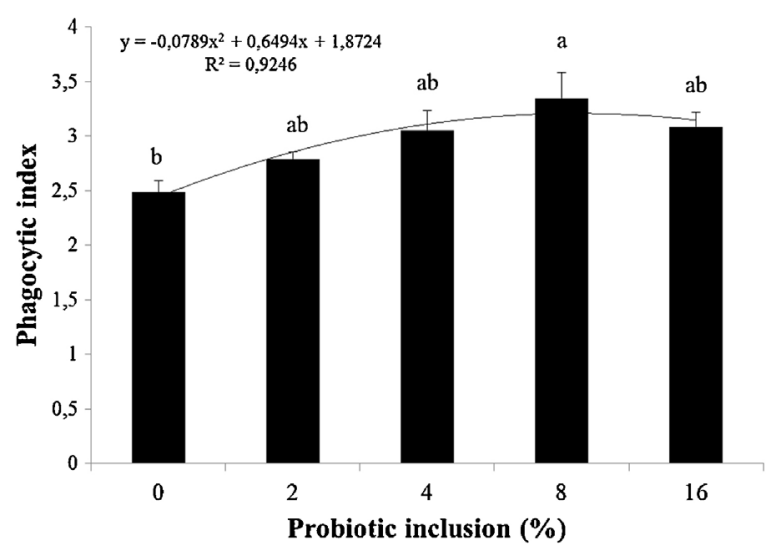

Fig. 1. Means values ( $n=6, \pm$ SE) for phagocytic index of Piaractus mesopotamicus fed with different levels $\left(0,2,4,8\right.$ and $\left.16 \mathrm{~g} \mathrm{~kg}^{-1}\right)$ of probiotic $($ Bacillus cereus and Bacillus subtilis, $1: 1,10^{8} \mathrm{CFU} \mathrm{g}^{-1}$ ) for 60 days ( $p=0.0036$, quadratic effect by orthogonal polynomial contrasts). 


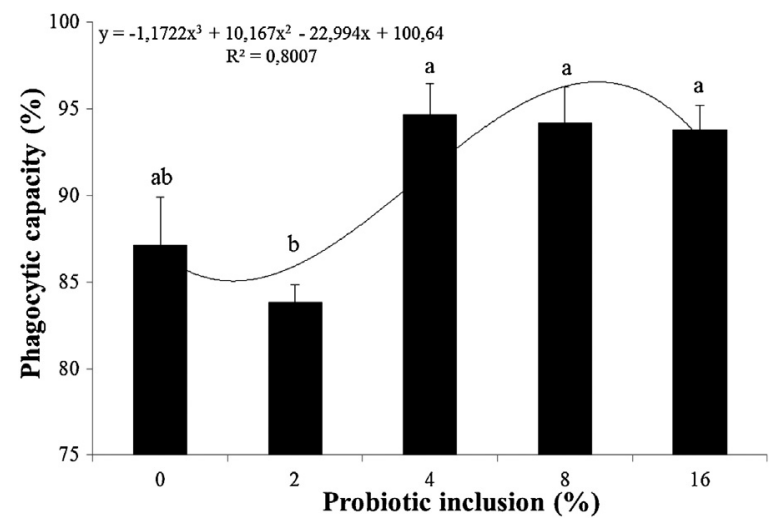

Fig. 2. Means values ( $n=6, \pm$ SE) for phagocytic capacity of Piaractus mesopotamicus fed with different levels $\left(0,2,4,8\right.$ and $\left.16 \mathrm{~g} \mathrm{~kg}^{-1}\right)$ of probiotic (Bacillus cereus and Bacillus subtilis, $1: 1,10^{8} \mathrm{CFU} \mathrm{g}^{-1}$ ) for 60 days ( $p=0.0008$, quadratic effect by orthogonal polynomial contrasts).

\subsection{Bacterial challenge}

All treated groups on diets containing the probiotic showed higher survival rates compared to the control group when challenged with A. hydrophila (Fig. 3). Clinical signs such as hemorrhagic petechiae on skin and fins, ascites, and isolation from the rest of the group started to appear $24 \mathrm{~h}$ post-challenge, and the first death occurred after $48 \mathrm{~h}$ post-challenge. After the sixth day, stabilization of the disease was observed, with no additional mortality. The experimental infection by $A$. hydrophila was confirmed through reisolation of the bacteria from the head kidney of the dying fish.

\section{Discussion}

There was no influence of probiotic inclusion on pacu productivity parameters after 60 days of feeding. However, some studies have shown positive effects of the supplementation of fish feeds with Bacillus sp. (Aly et al., 2008; Son et al., 2009; Dias et al., 2012). This may be due to an improvement in the digestive activity by vitamin synthesis and bacterial enzyme liberation, promoting better absorption/utilization of nutrients (Gatesoupe, 1999). Experimental conditions, mainly dissolved oxygen amount, temperature, $\mathrm{pH}$ and environmental microflora, seem to be the main reasons for the discrepancies in the literature regarding probiotic inclusion in fish feeds, influencing the establishment, proliferation and function of probiotic bacteria in the host intestinal tract (Das et al., 2008; Mehrim, 2009). In addition, the results of Apun-Molina et al. (2009) and Ridha and Azad (2012) indicate that, in order to promote fish growth, there is a necessity of a period longer than 60 days of probiotic feeding.

Probiotics feeding increased reactive oxygen species (ROS) production associated to elevated neutrophil and monocyte counts. However, fish fed with $16 \mathrm{~g} \mathrm{~kg}^{-1}$ of probiotics showed no significant correlation between ROS production and leukocyte counts. Respiratory burst is the rapid release of ROS and plays an important role in the immune system (Castro et al., 2014 b). It is a crucial reaction which occurs in phagocytes to degrade internalized particles and bacteria (John et al., 2002) and according to Gimbo et al. (2015), the nitroblue tetrazolium (NBT) assay is indicative of oxidative radical production from neutrophils and monocytes for use in defense against pathogens. Some studies have shown ROS production increases in fish

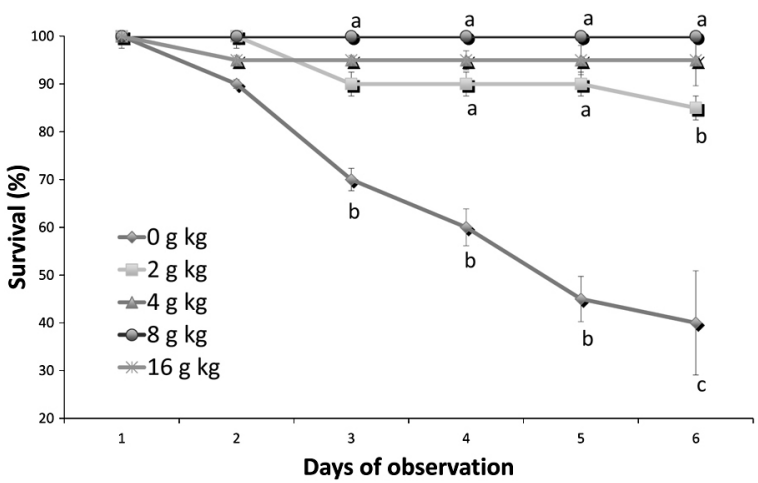

Fig. 3. Means values $(n=20, \pm$ SE) of the survival percentual of Piaractus mesopotamicus challenged with Aeromonas hydrophila strain after 60 days on diets containing different levels $\left(0,2,4,8\right.$ and $\left.16 \mathrm{~g} \mathrm{~kg}^{-1}\right)$ of probiotic (Bacillus cereus and Bacillus subtilis, $1: 1,10^{8} \mathrm{CFU} \mathrm{g}^{-1}$ ). Values followed by the same letter do not differ by the Tukey-Kramer test $(p>0.05)$, and lowercase letters compare the different treatments within each experimental day. 
on dieting different levels of the probiotic Bacillus, which was also affected by the time of administration (Panigrahi et al., 2004, 2005; Newaj-Fyzul et al., 2007; Giri et al., 2012).

The baker's yeast (S. cerevisiae) inoculum stimulated an inflammatory response in the coelomic cavity of pacus. Granulocytes as neutrophils and macrophages derived from monocytes are phagocytes involved in the internalization and destruction of pathogens and particles (such as yeasts) in the site of inflammation (Claudiano et al., 2013; Belo et al., 2014). The inclusion of Bacillus cereus and Bacillus subtilis $\left(1: 1,10^{8} \mathrm{CFU} \mathrm{g}^{-1}\right)$ in P. mesopotamicus diets increased the phagocytic index, only the $8 \mathrm{~g} \mathrm{~kg}^{-1}$ treated fish showed a statistically higher value when compared to the control group, but the regression analysis showed a dose-response effect between probiotic level of inclusion and number of phagocytized particles (yeasts). The inclusion of PAS-TR ${ }^{\mathrm{TM}}$ in P. mesopotamicus diets increased the phagocytic capacity (with the exception of the $2 \mathrm{~g} \mathrm{~kg}^{-1}$ group), although with no statistical difference compared to the control group. Some studies also showed improvements in the phagocytic activity of other fish species such as Oreochromis niloticus (Aly et al., 2008), Labeo rohita (Kumar et al., 2008), Solea senegalenses (Diaz-Rosales et al., 2009), Brycon amazonicus (Dias et al., 2012) on diets containing the probiotic Bacillus.

Improvements on immune status and higher resistance to A. hydrophila in P. mesopotamicus fed with different inclusion levels of $B$. cereus and B. subtilis in diets were observed. The manipulation of the intestinal microbiota by the inclusion of beneficial bacteria in aquatic organism diets have been noted as a viable alternative to antibiotic use as a prophylactic to disease outbreaks. Studies with the probiotic bacteria of group Bacillus have shown a positive overall effect, efficiently increasing host resistance to infectious agents through modulation of the immune system (Kumar et al., 2008), as observed in this study.

The probiotic inclusion in fish feed seems to be very effective in increasing the resistance of juvenile $P$. mesopotamicus to experimental infection with $A$. hydrophila. Several authors have seen a positive overall effect following the administration of probiotics as enhancers of fish resistance to pathogenic bacteria (Brunt and Austin, 2005; Vendrell et al., 2008; Sharifuzzaman and Austin, 2009; Gildberg et al., 1995; Vijayabaskar and Somasundaram, 2008). We hypothesize that the enhancement in fish defenses against this pathogenic bacterium comes from the systemic immunostimulation caused by the interaction between the probiotic Bacillus and the host's intestinal innate immune system.

\section{Conclusion}

The results demonstrated a dose response effect and the ideal level of the probiotic (Bacillus cereus and Bacillus subtilis, $1: 1,10^{8} \mathrm{CFU} \mathrm{g}^{-1}$ ) in P. mesopotamicus diets was around $8 \mathrm{~g} \mathrm{~kg}^{-1}$, as the highest survival rates and immunological responses were found in groups of fish fed with this diet. In addition, too much probiotic should be avoided, as pacus fed diet with $16 \mathrm{~g} \mathrm{~kg}^{-1}$ showed partial suppression of these responses.

\section{Conflicts of interest}

The authors declare no conflicts of interest.

\section{Ethical approval}

The experiment design was approved by Ethics Committee on the Use of Animals of São Paulo State University under the protocol n`22.518/10.

\section{Acknowledgements}

The authors thank IMEVE Company for donation of PAS-TR ${ }^{\mathrm{TM}}$ probiotic, Dr. Roberson Sakabe and M.Sc. Fernanda de Alexandre Sebastião for the help in experimentation, Dr. João Paulo Ramos da Costa by the statistical technical assistance, Professor Fernando Avila for microbiological analysis, M.Sc. Santiago Benites de Pádua for critical review of this paper and FAPESP (Fundação de Amparo à Pesquisa do Estado de São Paulo) for their financial support (project number 2010/14330-4).

\section{References}

Ahmed, S.M., Shoreit, A.A.M., 2001. Bacterial haemorrhagic septicemia in Oreochromis Niloticus at Aswan fish hatcheries. Assiut Vet. Med. J. 45, $190-206$.

Ai, Q., Xu, H., Mai, K., Xu, W., Wang, Zhang, W., 2011. Effects of dietary supplementation of Bacillus subtilis and fructooligosaccharide on growth performance, survival, non-specific immune response and disease resistance of juvenile large yellow croaker, Larimichthys crocea. Aquaculture 317 , $155-161$.

Aly, S.M., Ahmed, Y.A., Ghareeb, A.A., Mohamed, M.F., 2008. Studies on Bacillus subtilis and Lactobacillus acidophilus, as potential probiotics, on the immune response and resistance of Tilapia nilotica (Oreochromis niloticus) to challenge infections. Fish Shellf. Immunol. 25, 128-136.

Apun-Molina, J.P., Santamaria-Miranda, A., Luna-Gonzallez, A., Martínez-Díaz, S.F., Rojas-Contreras, M., 2009. Effect of potential probiotic bacteria on growth and survival of tilapia Oreochromis niloticus L., cultured in the laboratory under high density and suboptimum temperature. Aquac. Res. 40, 887-893.

Belo, M.A.A., Moraes, J.R.E., Soares, V.E., Maritns, M.L., Brum, C.D., Moraes, F.R., 2012. Vitamin C and endogenous cortisol in foreign-body inflammatory response in pacus. Pesqui. Agropecu. Bras. 47, 1015-1021.

Belo, M.A.A., Souza, D.G.F., Faria, V.P., Prado, E.J.R., Moraes, F.R., Onaka, E.M., 2013. Haematological response of curimbas Prochilodus lineatus, naturally infected with Neoechinorynchus curemai. J. Fish Biol. 82, 1403-1410. 
Belo, M.A.A., Moraes, F.R., Yoshida, L., Prado, E.J.R., Moraes, J.R.E., Soares, V.E., Silva, M.G., 2014. Deleterious effects of low level of vitamin E and high stocking density on the hematology response of pacus, during chronic inflammatory reaction. Aquaculture 422-423, 124-128.

Biller-Takahashi, J.D., Takahashi, L.S., Saita, M.V., Gimbo, R.Y., Urbinati, E.C., 2013. Leukocytes respiratory burst activity as indicator of innate immunity of pacu Piaractus mesopotamicus. Braz. J. Biol. 73, 425-429.

Boran, H., Terzi, E., Altinok, I., Capkin, E., Bascinar, N., 2013. Bacterial diseases of cultured Mediterranean horse mackerel (Trachurus mediterraneus) in sea cages. Aquaculture 396-399, 8-13.

Brunt, J., Austin, B., 2005. Use of a probiotic to control lactococcosis and streptococcosis in rainbow trout, Oncorhynchus mykiss (Walbaum). J. Fish Dis. 28, 693-701.

Cabello, F.C., 2006. Heavy use of prophylactic antibiotics in aquaculture: a growing problem for human and animal health and for the environment. Environ. Microbiol. 8, 1137-1144.

Castro, M.P., Moraes, F.R., Fujimoto, R.Y., Cruz, C., Belo, M.A.A., Moraes, J.R.E., 2014a. Acute toxicity by water containing hexavalent or trivalente chromium in native Brazilian fish, Piaractus mesopotamicus: anatomopathological alterations and mortality. Bull. Environ. Contam. Toxicol. 92, 213-219.

Castro, M.P., Claudiano, G.S., Petrillo, T.R., Shimada, M.T., Belo, M.A.A., Marzocchi-Machado, C.M., Moraes, J.R.E., Manrique, W.G., Moraes, F.R., 2014b. Acute aerocystitis in nile tilapia bred in net cages and supplemented with chromium carbochelate and Saccharomyces cerevisiae. Fish Shellf. Immunol. 31 , 284-290.

Castro, M.P., Claudiano, G.S., Bortoluzzi, N.L., Garrido, E., Fujimoto, R.Y., Shimada, M.T., Belo, M.A.A., Moraes, J.E.R., Moraes, F.R., 2014c. Chromium carbochelate dietary supplementation favored the glucocorticoid response during acute inflammation of Piaractus mesopotamicus. Aquaculture 432, $114-118$.

Claudiano, S.G., Petrillo, T.R., Manrinque, W.G., Castro, M.P., Loureiro, B.A., Marcusso, P.F., Belo, M.A.A., Moraes, J.R.E., Moraes, F., 2013. Acute aerocystitis in Piaractus mesopotamicus: participation of eicosanoids and pro-inflammatory cytokines. Fish Shellf. Immunol. 4, 01-06.

Crumlish, M., Thanh, P.C., Koesling, J., Tung, V.T., Gravningen, K., 2010. Experimental challenge studies in Vietnamese catfish, Pangasianodon hypophthalmus (Sauvage), exposed to Edwardsiella ictaluri and Aeromonas hydrophila. J. Fish Dis. 33, 717-722.

Das, S., Ward, L.R., Burke, C., 2008. Prospects of using marine Actinobacteria as probiotics in aquaculture. Appl. Microbiol. Biotechnol. 81, 419-429.

Dias, D.C., Leonardo, A.F.G., Tachibana, L., Corrêa, C.F., Bordon, I.C.A.C., Romagosa, E., Ranzani-Paiva, M.J.T., 2012. Effect of incorporating probiotics into the diet of matrinxã (Brycon amazonicus) breeders. J. Appl. Ichthyol. 28, 40-45.

Diaz-Rosales, P., Arijo, S., Chabrillon, M., Alarcon, F.J., Tapia-Paniagua, S.T., Martinez-Manzanares, E., Balebona, M.C., Moriñigo, M.A., 2009. Effects of two closely related probiotics on respiratory burst activity of Senegalese sole (Solea senegalensis, Kaup) phagocytes, and protection against Photobacterium damselae subsp. piscicida. Aquaculture 293, 16-21.

Gatesoupe, F.J., 1999. The use of probiotics in aquaculture. Aquaculture 180, 147-165

Gildberg, A., Johansen, A., Bogwald, J., 1995. Growth and survival of Atlantic salmon (Salmo salar) fry given diets supplemented with fish protein hydrolysate and lactic acid bacteria during a challenge trial with Aeromonas salmonicida. Aquaculture 138, $23-34$.

Gimbo, R.Y., Fávero, G.C., Montoya, L.M.F., Urbinati, E.C., 2015. Energy deficit does not affect immune responses of experimentally infected pacu (Piaractus mesopotamicus). Fish Shellf. Immunol. 43, 295-300.

Giri, S.S., Sen, S.S., Sukumaran, V., 2012. Effects of dietary supplementation of potential probiotic Pseudomonas aeruginosa VSG-2 on the innate immunity and disease resistance of tropical freshwater fish, Labeo rohita. Fish Shellf. Immunol. 32, 1135-1140.

He, S., Liu, W., Zhou, Z., Mao, W., Ren, P., Marubashi, T., Ringø, E., 2011. Evaluation of probiotic strain Bacillus subtilis C-3102 as a feed supplement for koi carp (Cyprinus carpio). J. Aquac Res. Dev., http://dx.doi.org/10.4172/2155-9546, S1-005.

John, M.B., Chandran, M.R., Aruna, B.V., Anbarasu, K., 2002. Production of superoxide anion by head-kidney leucocytes of Indian major carps immunized with bacterins of Aeromonas hydrophila. Fish Shellf. Immunol. 12, 201-207.

Kumar, R., Mukherjee, S.C., Ranjan, R., Nayak, S.K., 2008. Enhanced innate immune parameters in Labeo rohita (Ham.) following oral administration of Bacillus subtilis. Fish Shellf. Immunol. 24, 168-172.

Li, C., Beck, B., Su, B., Terhune, J., Peatman, E., 2013. Early mucosal responses in blue catfish (Ictalurus furcatus) skin to Aeromonas hydrophila infection. Fish Shellf. Immunol. 34, 920-928.

Mehrim, A.I., 2009. Effect of dietary supplementation of Biogen (Commercial probiotic) on mono-sex Nile tilapia Oreochromis niloticus under different stocking densities. J. Fish. Aquat. Sci. 4, 261-273.

Merrifield, D.L., Bradley, G., Baker, R.T.M., Dimitroglou, A., Davies, S.J., 2010. Probiotic applications for rainbow trout (Oncorhynchus mykiss Walbaum). I. Effects on growth performance, feed utilization, intestinal microbiota and related health criteria. Aquacult. Nutr. 16, 504-510.

Nayak, S.K., 2010. Probiotics and immunity: a fish perspective. Fish Shellf. Immunol. 29, 2-14.

Newaj-Fyzul, A., Adesiyun, A.A., Mutani, A., Ramsubhag, A., Brunt, J., Austin, B., 2007. Bacillus subtilis AB1 controls Aeromonas infection in rainbow trout (Oncorhynchus mykiss, Walbaum). J. Appl. Microbiol. 103, 1699-1706.

Panigrahi, A., Kiron, V., Kobayashi, T., Puangkaew, J., Satoh, S., Sugita, H., 2004. Immune responses in rainbow trout Oncorhynchus mykiss induced by a potential probiotic bacteria Lactobacillus rhamnosus. Vet. Immunol. Immunopathol. 102, 379-388.

Panigrahi, A., Kiron, V., Puangkaew, J., Kobayashi, T., Satoh, S., Sugita, H., 2005. The viability of probiotic bacteria as a factor influencing the immune response in rainbow trout Oncorhynchus mykiss. Aquaculture 243, 241-254.

Pridgeon, J.W., Klesius, P.H., Song, L., Zhang, D., Kojima, K., Mobley, J.A., 2013. Identification, virulence, and mass spectrometry of toxic ECP fractions of West Alabama isolates of Aeromonas hydrophila obtained from a 2010 disease outbreak. Vet. Microbiol. 164, 336-343.

Raida, M.K., Larsen, J.L., Nilsen, M.E., Buchmann, K., 2003. Enhanced resistance of rainbow trout, Oncorhynchus mykiss (Walbaum), against Yersinia ruckeri challenge following oral administration of Bacillus subtilis and B.licheniformis (BIOPLUS2B). J. Fish Dis. 26, 495-498.

Reque, V.R., Moraes, J.R.E., Belo, M.A.A., Moraes, F.R., 2010. Inflammation induced by inactivated Aeromonas hydrophila in Nile tilapia fed diets supplemented with Saccharomyces cerevisiae. Aquaculture 300, 37-42.

Ridha, M.T., Azad, I.S., 2012. Preliminary evaluation of growth performance and immune response of Nile tilapia Oreochromis niloticus supplemented with two putative probiotic bacteria. Aquac. Res. 43, 843-852.

Rigos, G., Troisi, G.M., 2005. Antibacterial agents in Mediterranean finfish farming: a synopsis of drug pharmacokinetics in important euryhaline fish species and possible environmental implications. Rev. Fish Biol. Fisher. 15, 53-73.

Sakabe, R., Moraes, F.R., Belo, M.A.A., Moraes, J.E.R., Pilarski, F., 2013. Kinects of chronic inflammation in Nile tilapia supplemented with essential fatty acids n-3 and n-6. Pesqui. Agropecu. Bras. 48, 313-319.

Salinas, I., Cuesta, A., Estaban, M.A., Meseguer, J., 2005. Dietary administration of Lactobacillus delbrueckii and Bacillus subtilis, single or combined, on gilthead seabream cellular innate immune responses. Fish Shellf. Immunol. 19, 67-77.

Sarkar, A., Saha, M., Patra, A., Roy, P., 2012. Characterization of Aeromonas hydrophila through RAPD-PCR and SDS-PAGE analysis. Open J. Med. Microbiol. 2, $37-40$.

SAS Institute Inc, 2008. SAS/STAT Software Changes and Enhancements Through Computer Program. Release 9.2. SAS Institute, Cary.

Sharifuzzaman, S.M., Austin, B., 2009. Influence of probiotic feeding duration on disease resistance and immune parameters in rainbow trout. Fish Shellf. Immunol. 27, 440-445.

Shotts, E.B., Rimler, R., 1973. Medium for the isolation of Aeromonas hydrophila. Appl. Environ. Microbiol. 26, 550-553.

Silva, J.R.M.C., Porto-Neto, L.R., Borges, J.C.S., Jensch-Junior, B.E., 2005. Germicide capacity of macrophages in the Antarctic fish Notothenia coriiceps (Richardson, 1844) at $0^{\circ} \mathrm{C}$. Polar Biol. 28, 326-328.

Silva, B.C., Mouriño, J.L.P., Vieira, F.N., Jatobá, A., Seiffert, W.Q., Martins, M.L., 2012. Hemorrhagic septicemia in the hybrid surubim (Pseudoplatystoma corruscans $\times$ P. fasciatum) caused by Aeromonas hydrophila. Aquac. Res. 43, 908-916 
Son, V.M., Chang, C.C., Wu, M.C., Guu, Y.K., Chiu, C.H., 2009. Dietary administration of the probiotic, Lactobacillus plantarum, enhanced the growth, innate immune responses, and disease resistance of the grouper Epinephelus coiodes. Fish Shellf. Immunol. 26, 691-698.

Sun, Y.Z., Yang, H.L., Ma, R.L., Lin, W.Y., 2010. Probiotic applications of two dominant gut Bacillus strains with antagonistic activity improved the growth performance and immune responses of grouper Epinephelus coioides. Fish Shellf. Immunol. 29, 803-809.

Vendrell, D., Balcazar, J.L., Blas, I.D., Ruiz-Zzarzuela, I., Girones, O., Muzquiz, J.L., 2008. Protection of rainbow trout (Oncorhynchus mykiss) from lactococcosis by probiotic bacteria. Comp. Immunol. Microbiol. Infect. Dis. 31, 337-345.

Vijayabaskar, P., Somasundaram, S.T., 2008. Isolation of bacteriocin producing lactic acid bacteria from fish gut and probiotic activity against common freshwater fish pathogen Aeromonas hydrophila. Biotechnology 7, 124-128.

Xia, C., Ma, Z.H., Habibur Rahman, M., Wu, Z.G., 2004. PCR cloning and identification of the haemolysin gene of Aeromonas hydrophila from freshwater fishes in China. Aquaculture 229, 45-53.

Yanbo, W., Zirong, X., 2006. Effect of probiotics for common carp (Cyprinus carpio) based on growth performance and digestive enzyme activities. Anim. Feed Sci. Technol. 127, 283-292.

Zhou, X., Tian, Z., Wang, Y., Li, W., 2009. Effect of treatment with probiotics as water additives on tilapia (Oreochromis niloticus) growth performance and immune response. Fish Physiol. Biochem. 36, 501-509. 